\title{
The Guggenheim Museum Helsinki Plan as a Media Debate
}

\author{
Maaria Linko
}

\section{Introduction}

In connection with today's competition between cities to portray an alluring image of economic and cultural success, The Solomon R. Guggenheim Foundation, at the request of the City of Helsinki, submitted a museum plan to the city council in 2012 to establish a Guggenheim museum in Helsinki, Finland. Following its release in the media, a heated public debate on the plan to invest in an American museum brand emerged in Helsingin Sanomat, the eminent newspaper of the capital region. The present article analyzes this media conflict and aims to show in what ways the debate affected the decision-making process concerning whether to establish a Helsinki Guggenheim museum. It discusses the failures of the museum project to motivate different stakeholders proactively and to respect the democratic process in city planning.

The debate on Guggenheim Helsinki started in January 2012, when the Guggenheim Foundation published a Concept and Development Study for a Guggenheim Helsinki ${ }^{1}$ and announced its intention to build a new museum in Helsinki. The cost of the report produced by the American consultant companies (LaPlaca Cohen; Boston Consulting Group; Cooper, Robertson \& Partners; Roschier) was 2 million euros. The cost was covered by the City of Helsinki and two Finnish private foundations, The Swedish Cultural Foundation and The Finnish Cultural Foundation. According to the report, the city would also cover the investment for the new building, the museum's maintenance, including the staff, and hence, the City would shoulder the economic risk. The building was to be in the possession of the City of Helsinki, which, in addition, would pay 20 million euros over 20 years for the Guggenheim brand. Decision-making on the exhibition policy and content would be solely in the hands of the Guggenheim Foundation. The Foundation required a decision at short notice. The estimated number of visitors ( 0.5 million per year) and the Foundation's intention to feature design and architecture were included in the report. What Helsinki would get, according to the report, would be a museum connected to 'a prestigious' international network that organized exhibitions and shared museum expertise.

The idea of bringing a new international museum to Helsinki emerged within the context of a large number of flagship buildings for cultural purposes having already been established around Europe as part of inner-city development strategies pursuing important economic aims (Richards 2001; Aalst and Boogarts 2002; Evans 2003; Evans 2005; Plaza and Haarich 2009: 259; Ponzini 2010; Markusen and Gadwa 2010). Since its opening, the Guggenheim museum in Bilbao, Spain and other flagship cultural buildings have been the subject of lively discussions in cultural policy, cultural economics, urban sociology, and city planning. These discussions include the influence of the museum in attracting tourists (Plaza 2000; Plaza 2008; Ponzini and Nastasi 2011), its effects on the art scene of Bilbao (Plaza et al. 2009), analyzing the place of arts in urban planning (Evans 2005; Markusen and Gadwa 2010; Paül i Agusti 2014) and the effects and challenges of a major cultural investment in the economy of a city (Plaza 2006; Plaza et al. 2009). Meanwhile, major investments in buildings of cultural institutions in Northern Europe, such as the relatively new opera houses in Oslo, Copenhagen, and in Hamburg's HafenCity, are part of the same development (Desfor and Jørgensen 2004; Smith and von Krogh Stand 2011). All these flagship buildings are located at waterfront sites as the planned Guggenheim museum in Helsinki was to be. 
As the motivations behind plans for new museum complexes are bound up in urban and cultural policy as well as in the economy of cities, it is worth looking at the heated public and media debate on the Helsinki's Guggenheim museum plan, analyzing the process leading to its rejection. This article aims to examine what arguments, and by whom, were represented as justifications for the different views in this debate. It will argue that media, including various forms of social media, not only report conflicts but also act as co-constitutive in the processes of how conflicts develop and spread (Hjarvard 2008, Hjarvard et al. 2015). Finally, the article discusses the reasons why the debate grew heated and the museum plan was rejected.

The analysis is inspired by Luc Boltanski's and Laurent Thévenot's (1999; 2006 [1991]) theory of critical judgement. This theory focuses on conflicts that interrupt day-to-day action and the ways in which these conflicts are resolved by using commonly accepted sets of values in argumentation. According to Boltanski and Thévenot, the presuppositions of our actions become visible in conflict situations. However, the commonly accepted values usually prevent conflicts from escalating. These values are present in arguments, 'claims' used by groups participating in conflicts. The claims in public conflicts rely on arguments that different groups recognize as legitimate, even if participants of the conflict or debate did not agree with them. The commonly shared basis for arguments that refer to different traditions of making sense of reality are called worlds, and justifications in Boltanski's and Thévenot's conceptualization are value-based arguments rooted in these worlds.

The underlying presumption in the theory of critical judgement is that in their arguments, different groups of actors use different 'worlds' of justification, namely inspiration, market, renown, civic, domestic, industrial and green. In Boltanski's and Thévenot's (1999; 2006 [1991]) conceptualization, the world of inspiration refers to arts, the imagination, creativity, and living experiences. In the world of the market, the value of investments or agency are assessed in financial terms. In the civic world, for its part, the focus is on the importance of the general well-being and common good of citizens, and unity is formed by a convergence of human wills as citizens direct themselves towards a common good. Commonly accepted agreements are valuable in the civic world. In the world of renown (or fame), worth is the result of general opinion. The typical means in this world are trademarks, messages, press releases and so on. In the Guggenheim's case, comments on the Guggenheim brand, the fame of Helsinki and its tourism reflect justifications stemming from this world. The domestic world refers not only to private settings but to traditions, positions in hierarchies and personal networks as well. The industrial world refers to emphasis on efficiency, planning, regulations and agreement. Finally, the world of green (ecology) relates to ecological values. Accordingly, the empirical analysis of the Guggenheim conflict is based on a methodological application developed from Luc Boltanski's and Laurent Thévenot's theory (Luhtakallio and Ylä-Anttila 2011; Luhtakallio 2012; Ylä-Anttila and Kukkonen 2014).

The following analysis of the Guggenheim debate is concentrated on the most commonly used justifications of this specific case. These justifications rely on the worlds of market, inspiration, industry, citizenship and renown whereas the domestic world (home) was referred to only rarely and the world of green was practically absent in the Guggenheim Helsinki debate (see Table 1). The underlying presumption of the analysis is that the media reports as well as modifies the debate. Further, individual claims during the debate may rely on justifications from different worlds at the same time (Boltanski and Thévenot 2006 [1991]: 21, 177-9; Luhtakallio 2012: 152-4).

\section{Boosting the Economy and Branding of Cities with Flagship Buildings}

Since the successful and well documented revitalization process of Glasgow generated by the European Union Capital of Culture designation and by active policy, which changed the cycle of its urban decay in 1990, city officials around the world have been inspired by research indicating that investing in culture brings economic and social benefits. These investments bring vibrancy, visitors and new work opportunities (Bianchini et al. 1993; Aalst and Boogarts 2002; García 2004; Plaza et al. 2009; Markusen and Gadwa 2010; Grodach 2013; Paül i Agusti 2014). The analysis pertaining to the Guggenheim debate is a part of this wider discussion on urban development and restructuring the economy of cities. In the new economy of urban planning and its stress on tourism, global and national forces merge. 
Often, museums are centrepieces in such development projects in urban areas. As flagship buildings for culture and tourism, they are expected to symbolize their cities. Hopes for urban economic growth have been linked to these investments (Plaza and Haarich 2009; Plaza and Haarich 2015). High profile cases from the 1990s, of which the most well-known is the Guggenheim museum in Bilbao, in the Basque country of Spain, have inspired many new culture-led projects. Guggenheim Bilbao is definitely a tourist magnet: fifteen years after its opening, in 2012, it reached approximately a million visitors, of whom 62 per cent were foreigners, and in 2018, the number of visitors had risen to around 1.3 million.

The Guggenheim museum, together with a major urban renewal program, has transformed Bilbao from a post-industrial 'fly-over' to a popular tourist destination, and the city has benefited from this in many respects (Plaza 2008). Before the Guggenheim, Bilbao was not a tourist destination and no specific potential for the future was seen to that end (Ponzini and Nastasi 2011: 28-9). The change has been profound, and the museum building is a centrepiece of 'starchitecture' (Ponzini and Nastasi 2011). Inspired by the success of the formerly decaying city, the media generated the terms 'Guggenheim effect' and 'Bilbao effect' terms quickly adopted by policy-makers in urban development as well as by researchers (Plaza et al. 2009: 1711). These concepts refer to a phenomenon in which architecturally lucrative flagship buildings designed by famous architects become must-see tourist destinations and tools to enhance the city's economy and reputation (Ponzini 2010).

However, Bilbao's success is based not only on the opening of the museum but also on a much larger and coherent public policy targeted at productivity and diversity with a strong cultural component. Firstly, the city invested in infrastructure, such as public transport and parks, and as with the Guggenheim museum, investments in arts and cultural heritage generated cultural tourism (Plaza 2008). Secondly, art-supporting networks are one of the main outcomes of the Bilbao Guggenheim: Beatrix Plaza, Manuel Tironi and Silke Haarich (2009: 1725-6) showed that the museum has had positive impact on the local arts sector and artists have become more international.

Research into Guggenheim Bilbao's effects in the city has shown, however, that Bilbao's success story has been a very specific individual case, and most probably could not be repeated elsewhere (Baniatopoulou 2001; Evans 2003; Plaza 2008; Plaza and Haarich 2008; Grodach 2010; Ponzini and Nastasi 2011: 26-43). Flagship cultural projects are dependent on a variety of contextual factors and, therefore, should be positioned to build on existing arts and related commercial activity (Grodach 2008; Plaza and Haarich 2008: 270; Grodach 2010: 362-3). Even then, the positive outcome should not be taken for granted.

From Glasgow to Newcastle and from Oslo to Copenhagen, alongside the Guggenheim Bilbao museum, there are numerous other museums and other building projects for culture located at the waterfront, whose main goal is to foster economic renewal (Miles 2005; Bayliss 2007). Research in cultural regeneration in cities indicates that redeveloped urban waterfronts can remain poorly connected with the rest of the city, physically, but also socially and economically. City dwellers as well as visitors experience the waterfront development projects as soulless, segregated and gentrified spaces. However, some have met with public approval (Desfor and Jœrgensen 2004; Smith and von Krogh Strand 2011). A positive example from Scandinavia is Oslo's Opera House. Smith and von Krogh Strand (2011) investigated the justifications for the Opera House project among stakeholders responsible for this flagship project. According to Smith and von Krogh Strand the new Opera House is best understood as a cultural and national symbol (in addition to a house for opera performances, which was much needed), although it was also designed to assist urban regeneration and development. The Opera House functions as a marketing symbol as well as a visitor attraction. Attention to public access - visitors are welcome to walk on the wide roof of the building at the waterfront - combined with eye-catching architecture instead of pure monumentality is a key element in attracting visitors.

In London, Nicholas Serota and Donald Hyslop (2011: 336) analyzed the founding of Tate Modern at the Thames and crystallized the requirements for any large urban renewal process. A key one is to keep the relevant organizations local, national and international at the same time. Activities should be maintained at all three levels and bonds developed between them. Culture-led development is possible if the interests of the different sectors of urban life, 
including political and business life, are part of the development in a fair and balanced manner, Serota and Hyslop conclude. In many cases these requirements are not met properly - the Guggenheim Helsinki museum plan is an example of this challenge.

In the following section, the fate of the plan to build a Guggenheim Museum at a waterfront site in the centre of Helsinki is discussed by analyzing the arguments expressed by different stakeholders in the media after the release of the plan. Further, the analysis of the data is followed by a discussion on how the balance between different views developed during the debate. Could the clash between stakeholders have been avoided and, if not, did Helsinki lose an exceptional opportunity to develop its arts scene and establish a new visitor attraction or was the decision not to build a museum for the common good?

\section{The Guggenheim Museum Helsinki Debate}

The Guggenheim debate occurred in different phases. ${ }^{2}$ In the first phase (in 2011) the possibility of a new Guggenheim opening in Helsinki was made public by the mayor and vice-mayors and the chief-negotiator of the City of Helsinki together with the management team of the Guggenheim Foundation. The most heated debate took place in the second phase right after the museum report was published in $2012 .{ }^{3}$ The analysis of this research concentrates on this debate. After the city board's decision to reject the museum plan in May 2012, the debate cooled. In 2013, the Guggenheim Foundation started new negotiations with the City and made a new proposal to the City of Helsinki. The detailed analysis of this paper focuses on the debate following the first report (2012), with discussion on the second report (2013). By the end of 2016, the project was buried. ${ }^{4}$

First introduced to the public in January 2011, Helsinki mayor Jussi Pajunen and the Helsinki Art Museum director and chief-negotiator Janne Gallén-Kallela-Sirén emphasized the benefits the museum would bring to the city, and revealed that the motivating ideal behind the project was the success of the Guggenheim museum in Bilbao. However, the city officials and the Guggenheim Foundation emphasized that the building itself, a flagship structure with a strong wow-factor and famous brand, would be less important to the project and that a completely new museum concept would be planned instead.

At first, there was a great deal of enthusiasm about the project: the request for a museum plan from the Guggenheim Foundation was presented as a piece of good news in the Helsingin Sanomat editorial of 19 January 2011. The newspaper clearly took a stand on the plan by seeing a great opportunity for the Helsinki Metropolitan Area and the whole country were the museum to be built. Advantages for the arts community in terms of stronger international visibility were also pointed out by the negotiators. Further, the calculated 4.5 million euro increase in city revenue was emphasized. The Guggenheim Foundation explained that Helsinki, being a gateway to the east, especially to Russia, was an important factor in their interest in Helsinki specifically ('Helsinki wants Guggenheim', Helsingin Sanomat 19 January 2011). The management of the city did not encourage public discussion at this stage and suggested waiting for the museum report. In retrospect, a more inclusive discussion from the beginning could have led to a different result, as the analysis of the first phase of the Guggenheim Museum Helsinki debate attempts to show. In light of the findings of my research, the agency of the citizens and other stakeholders should have been given room immediately after the idea of a 'new museum concept' was made public and the report was developed to avoid a feeling that plans for a major investment were being made behind closed doors. As well as the subject of 'taxpayers' money', the debate examined in the next section deals with the question of whether Helsinki is interesting as a city of culture as it is, or would it become interesting in the eyes of visitors and residents, and more open to current international influences, with the help of a Guggenheim museum. The debate grew very heated, as will be illustrated below, with opponents of the museum not accepting that new ideas would flow from a Guggenheim. These topics were also the subject of dispute in the political arena.

\section{Research Data and Methodology}

The primary research data consisted of articles (including letters to the editor) from Helsingin Sanomat [HS] in 2012. In a country of 5.4 million people (in 2012) Helsingin Sanomat is a 
major influencer within the media industry (with more than 850,000 readers, it is the only daily newspaper in the capital region) and its monopoly as a news medium in matters of the capital region is common knowledge in Finland.

The most intense period of debate took place during the first four months of 2012, with 137 published articles and other items in the Helsingin Sanomat newspaper. This particular data, limited to the HS newspaper, where the debate started and grew heated, was analyzed in detail by using an analytical tool based on the theory of justification by Boltanski and Thévenot (Luhtakallio and Ylä-Anttila 2011; Luhtakallio 2012: 152-54, Ylä-Anttila and Kukkonen 2014). In the analysis of justifications, the research data were coded by applying seven worlds of justifications to the arguments. From each article, the main argument ('claim') was extracted and the world of justification it leaned towards was coded (see Table 1). In some cases, two or a maximum of three different worlds of justification were coded for each article if they appeared equally strong. Thus, one article and its core claim could include justifications from different worlds. Also, different actors behind the different opinions or 'claims', the genre of different items, as well as the general attitude of individual items (positive/negative) were coded. The basic idea of the justification analysis was to acquire a systematic view of the arguments used both in favour and against the museum and the worlds they leaned towards, and to see how the attitudes changed during the debate. Two research assistants coded this core data.

Along with the justification analysis of newspaper articles, a thematic qualitative analysis was applied to a secondary body of data. This includes readers' comments (136 items) on the newspaper's web pages between 10 January and 7 February 2012. It also includes Facebook comments in two relevant groups between 26 January and 2 February 2012 (128 items) continued with a Facebook chain, where the mayor of Helsinki Jussi Pajunen answered the city dwellers' comments (121 items) on 16 April 2012. Further, the subsequent public discussion on Guggenheim in 2013 in Helsingin Sanomat, blog posts by two art critics, a museum director and an economist of culture and three articles in a quality magazine, Suomen Kuvalehti, were subject to qualitative analysis by close reading of the material and categorizing of the main arguments.

Six distinct actors participating in the museum debate were distinguished from the core data: citizens, art world, media, the City of Helsinki, political actors, and the Guggenheim Foundation. The citizens took part in the debate in the HS newspaper as ordinary residents, many of whom mentioned their profession in the letters to the editor, for example. The art world consisted of museum directors and other staff members of various museums and artists' organizations, artists, gallery owners and art critics. Media here refers to editorial material of HS representing the media as an independent actor. The Mayor of Helsinki and other city managers, as well as the director of the City of Helsinki art museum (the initiator and chief consultant in the project) were the actors of the city in the debate. The political actors comprised group leaders and other members of the city council, as well as MPs, including members of government. The Guggenheim Foundation is considered as an actor even though it scarcely took part in the debate and restricted its presence in the media to released business propositions, probably due to reputation management reasons. The next chapter contains the analysis of justifications.

\section{Clash of Justifications: Inspiration Gives Way to Reasoning of the Market}

The most intense debate took place after the release of the museum plan: within a week, 78 items, and within four months, 137 items on the subject were published. As already mentioned, at first, $H S$ took a stand in favour of Guggenheim Museum Helsinki plans. The paper says in its editorial (11 January 2012) that:

Guggenheim should be considered as an investment - both intellectual and economic. Were the museum launched, no organization in the art world could continue as if a change had not happened. A new museum would produce energy and new ways of thinking. A new international museum would enhance the lucrativeness of the capital region and bring visitors who, for their part, would create demand in services and jobs. 
As the debate broke out, the newspaper published critical views by different actors as well, even if the editors of the newspaper were in favour of the museum. No claims of limiting criticism in the paper came out.

As is shown in Table 1, during the intense debate, the world most referenced in the argumentation was that of the market. Scepticism about financing and maintaining the museum were the main points. 'We cannot afford it' was the dominant message in the debate.

\begin{tabular}{|l|c|}
\hline Justification ('worlds') behind arguments & $\mathrm{N}$ \\
\hline Inspiration & 37 \\
\hline Home & 14 \\
\hline Renown & 26 \\
\hline Citizenship & 35 \\
\hline Market & 66 \\
\hline Industry & 38 \\
\hline Ecology & 3 \\
\hline Total & 219 \\
\hline Total no. of articles: 137, Helsingin Sanomat (1-3 arguments coded/item) & \\
\hline
\end{tabular}

Table 1. The justifications behind central arguments in the Guggenheim Helsinki debate in Helsingin Sanomat between January 2012 and May 2012.

Citizens were the most active participants or stakeholders (60 articles) during the debate in Helsingin Sanomat. Their opinions appeared predominantly in letters to the editor but also in interviews. The journalists and editors expressing their own views in editorials and columns were the second most active group (30 articles), with the art world and the politicians next, with approximately 23 and 20 articles respectively. Citizens formed a diffuse group ranging from city dwellers who didn't reveal their occupation to well-known members of the so-called creative class. A few members of this group represented the views of economic life. In general, active citizenship mainly expressed in letters to the editor was a common feature uniting them. Immediately after the launching of the Guggenheim report, opinions among citizens were evenly divided in favour of and against Guggenheim. At this point, the citizens looked at the project from the point of view of art, inspiration and fame. Those interested in Finland's international reputation saw fame as more of a booster of economic success:

I have lived abroad for a long period of time and Guggenheim in Helsinki would be the best thing to happen to the cultural image of the city. We don't need a Guggenheim because the image of Helsinki is negative but because the Guggenheim is a well-known museum and it would signify recognition of our know-how (HS, 13 January 2012).

The exhibitions or collections of the future museum were not at the centre of the debate. Therefore, it is interesting to note that active citizens - instead of the directors of different museums, artists' organizations and other members of the art world - were interested in the art that the museum could offer: 'As far as I'm concerned, the exhibitions of a Guggenheim museum would be the most important thing, because I can't afford to travel abroad to see them' (HS, 13 January 2012).

Some citizens connected exhibitions - the world of inspiration in Boltanski's and Thévenot's (2006 [1991]) terms - to the future success of the city. 'A Guggenheim would open new channels for Finnish culture to be noticed in the outside world' (HS, 13 January 2012) was an opinion repeated a few times. Justifications for arguments leaned towards the world of industry, referring to contracts, networks, development etc., more than to the world of inspiration or the civic world. 
Citizens against a Guggenheim museum often pinpointed other, more urgent targets for investments, such as a new children's hospital. These comments can be interpreted as expressions of instrumentalism typical of reactions to any investments in culture (Gray 2007; Gibson 2008; Hadley and Gray 2017). After the release of the first Guggenheim report, argumentation using the world of inspiration diminished, and justifications from the world of the market, in terms of questions about the cost of the project, as well as the use of public money, became central. During the first and most intense week of the debate after the publication of the Guggenheim report, some 43 articles included justifications based on the economy (market) and some 20, that of inspiration. As a citizen writes in a letter to the editor (HS, 11 January 2012),

The estimated cost of a new museum building is 140 million euros. As it happened, when building the new Music House [in Helsinki], the estimated costs for the building were wide of the mark. What about the maintenance costs? It seems probable that it will be the taxpayers who foot the bill.

After the publication of the Guggenheim report, the discussion moved immediately from the world of inspiration to the world of the market and comments on the web pages of Helsingin Sanomat concentrated on this issue. Art and the possibility of broadening human experiences introduced before the publication of the plan did not inspire comments on the web pages of $H S$. The project became primarily an economic issue. Following this development, it was no longer as relevant to comment using justifications from the world of inspiration, even given the residents' opinions on Guggenheim's cultural relevance and urgency compared with other cultural projects. Other cultural activities were also preferred: 'Let's hope that public money is used for taking care of the elderly, and taking school children to opera festivals, theatre, science centres etc. What we already have should be made more accessible and interesting' (HS 18 January 2012). Critical views also included expressions of values of nationalistic ideology, which could clearly be seen in the arguments of Guggenheim opponents: '[...] Isn't it right to be assured that Finland is one of the few countries in the world who has managed and still manages its issues well. We don't need appraisal bought with money or the approval of other countries. Let's be proud of being Finns instead' (HS 12 January 2012). Another commentator said that 'the Guggenheim concept might suffer from inflation because of being so common. Let's start planning our own authentic Finnish idea for this area' (HS 17 January 2012).

Interpreted within the framework of increased global interdependency and strong populist movements in Europe, these comments send a message of inward orientation. In current political and cultural climates, some individuals may see evident changes as a threat to their own culture and react by overstating the achievements of a small nation under the pressure of stronger coalitions of power (Bauman (2001 [1997]); Mickelsson 2012: 107-8). In their election campaign, Finland's right-wing populist party even waded into the artistic domain by expressing its disapproval of 'fake postmodern art' in favour of Finnish naturalism. Support for this party has risen substantially with the increasing economic turbulence and migration in Europe. From the point of view of arguments against the Guggenheim museum, this type of reasoning, arising from nationalistic ideology, reflects a domestic world in which tradition is highly valued. Helsingin Sanomat comments on these attitudes in its editorial by saying that a parochial and overly self-content atmosphere has grown stronger in Finland, at a time when this country has had more opportunities to influence European politics than ever before. According to Helsingin Sanomat, at times of structural changes in the economy, a formerly innovative nation turns its back on integration, and turns its gaze to the past $(H S$ 11 March 2012). Furthermore, the world of ecology was never used in the justifications even if combining art and sustainability has become a topic of discussion and action in other European countries, particularly in Germany (Kagan and Kirchberg 2008). Some writers required a wooden building, but they referred to Finland's design history and know-how rather than fighting climate change.

At a press conference following the release of the Guggenheim report, representatives of the Foundation dictated a very tight schedule for the implementation of the project. Many of those present had the impression of a sales pitch in which the customer is made to feel that they are losing a great opportunity if the decision to purchase is not made instantly. This might 
have led to suspicion of the Foundation's motives. In democratic decision-making processes, projects that involve public investments never proceed at this speed. Rather, investments proceed in a process where planning, preparation and suggestions are made to the city board (with advance preparations by city officials, consultants and boards and committees), which decides which suggestions are brought to the democratically elected city council for final decision. ${ }^{5}$ The Foundation was reluctant to take part in the public debate or expand upon the report, which created an impression of secrecy. The tight schedule did turn out to be a mere negotiation tactic: after the rejection of the plan by the city board, the Foundation expressed willingness to wait for a positive decision (HS 3 May 2012).

Public opinion also changed during the debate. According to a survey (TNS Gallup March 2012), ${ }^{6}$ three quarters of the inhabitants of Helsinki agreed that a Guggenheim museum was not needed in the city and that a new building for the city library was more important. In contrast, some 59 per cent of HS readers had earlier (19 January 2012) agreed with the following question: 'Would it be great to have a new international art museum in Helsinki?' $(N=13,500)$. These slightly different surveys reflect the change that occurred in less than two months. The analysis of the readers' reactions (136 items) posted on the newspaper's web pages revealed that the change in opinion took place much earlier, already in January during the first week of the debate. Readers were highly critical of the politicians' and city officials' actions and the cost of the museum, and the justifications relied mostly on the world of the market.

Only after a week, and some very strong debate, Helsingin Sanomat also became more critical. A feature entitled 'The truth about "rejected" Guggenheims' on 18 January 2012 listed twelve Guggenheim plans that had been rejected since 1990, and the vice director of the Guggenheim Foundation, Eleanor Goldhar, was asked to comment on these projects. According to Goldhar, the immense success of Guggenheim Bilbao led to queries from numerous cities about the possibility of a Guggenheim museum being built in their area. This is how the 'business of Guggenheim reports' got started.

A key to understanding the suddenness of the turn in public opinion is citizen media on newspapers' webpages and social media. Following the release of the plan (11 January 2012), the immediate flow of comments on Helsingin Sanomat webpages and Facebook, as well as tweets, altogether produced a change in climate. The comments were critical of Guggenheim. People from different social worlds wanted to express their thoughts, and many ideas about cultural policy emerged outside the professional domain. On Facebook, the most common arguments dealt with the economy and were backed up by justifications from civic life, with emphasis on the needs of public life: investments should be made to just anything instead of a Guggenheim Museum. The needs of the elderly, children or existing museums among other things were foregrounded. Strong reactions from citizen media forced the news reporting and mainstream political thinking into a more reflexive or defensive position. Indeed, social media and the active commenting by readers in traditional media acted as an independent institution with a logic of its own which other social institutions must listen to. This process, defined as mediatization (Hjarvard 2008; Strömbäck and Esser 2015), turned members of the public into curators, sharing, evaluating and commenting on news and opinions in social media (Rosenbaum 2011; Villi 2012). ${ }^{7}$ This was true in the Guggenheim Helsinki case and therefore the debate can be described as a mediatized conflict (Hjarvard 2013; Strömbäck and Esser 2015).

At the time of the museum plan's release, the attitudes of politicians concerning the museum were not as divided as they became less than two weeks later. Some divisions were clear from the beginning, however. The minister of culture (the Left Alliance) opposed the museum straight away, as did the right-wing populist Finns Party. Almost all conservatives were in favour of the project: the Prime Minister Jyrki Katainen (National Coalition Party) saw in Guggenheim Helsinki an exceptional opportunity to export art, design and architecture, and saw a positive effect on tourism in the whole country (HS 13 Jan 2012). The Social Democrats were divided, as were the Greens (Ponzini and Ruoppila 2018). The politicians' reasoning consisted of legitimations from the world of the market and the world of industry. In practice, the questions about financing the project and the place of the museum among other city responsibilities were predictably in their interests, their main duties being decisions on 
public expenditure and ensuring public services. A new building for the city art museum and its collections, and supporting the careers of Finnish artists should, members of the art world argued, be the targets of investment. Otherwise, money would flow to a private American foundation, and a large proportion of the visitors would be tourists. With some exceptions, museum directors and art critics had little or no trust in the prospects of a Guggenheim boosting the Finnish art scene. Common disapproval was expressed towards the project's chief consultant, who - at least in public - seemed to show little interest in the future of his own establishment, the Helsinki Art Museum and its staff (HS 3 February 2012).

Representing the art world, a couple of internationally accomplished artists, two museum directors and a proportion of citizens were positive about the project. A proper dialogue between representatives of different views never took place, however. Repeated close reading of the newspaper debate shows that a great majority of the many different comments were outbursts of the interviewees' or writers' opinions without an effort to comment on other viewpoints. The differences between stakeholders using different justifications can, in some cases, turn out to be irreconcilable because they depend on profoundly different ways of making sense of reality, based on different normative principles, Sacha Kagan (2011) has argued. It is likely that this was the case in the Guggenheim debate.

\section{The Reasons for the Rejection of the Helsinki Guggenheim Museum Plan}

The economic risk that would be carried by the City of Helsinki, leading to doubts among different groups, proved the most evident but not the only reason for the rejection of the Guggenheim museum plan. Instead, the launching of the plan can be interpreted as a process in which significant failures in planning, networking, and communications led to a very limited number of important advocates for the project. Had the relevant ministries, local arts community and existing museums and other important stakeholders been aware of the aims of the museum project before it was made public, perhaps the Guggenheim Foundation would not have been seen so strongly as a rival to existing museums. In all, the City of Helsinki applied a top-down model of decision making and poorly disseminated the content of the plan in a modern and open democracy with active citizens. The general public was not motivated by being offered information about the Foundation's aims and its previous exhibitions. There was an assumption that the public knew about the Guggenheim Foundation, while in fact, many residents were unaware of it.

The debate gives the impression that the relationships between local, national and international art in the museum's exhibitions had not been considered beforehand and not even during the debate. At first, the Guggenheim Foundation announced that the museum would have no permanent collections. As the debate intensified, the Foundation backed away from this view, but the public was not informed of planned collections and which stakeholders would finance them. The exhibition plans and museum activities were also overshadowed by a debate on the museum's financing. 'The whole new museum concept', which was the starting point for the entire project, remained vague when the museum plan was released. A similar case took place in the city of Seoul, in which the mayor's design-based policies failed because of a lack of communication and collaboration (Lee 2015).

The Helsinki Guggenheim plan seemed to be 'an art project within urban policy instead of being an urban project within arts policy'. This definition was coined by urban sociologist Pasi Mäenpää in a public lecture on the Guggenheim plan in 2011, which implied that the contribution of a Guggenheim museum to the economic success of the city was the basic motivation for the city management to start negotiations with the Guggenheim Foundation (Mäenpää 2011). Using Carl Grodach's (2013) terminology in his analysis of cultural economy planning practices, the Guggenheim Museum Helsinki case clearly represents conventional economic development.

The analysis of justifications (Boltanski and Thévenot 1999; Luhtakallio 2012: 149-75) of the Guggenheim debate applied in this study combined with qualitative close reading of the media data indicate that the set of values among the different actors were so polarized that, despite the debate, any proper dialogue did not take place. Typically, a commentator leaning on justifications based on the world of inspiration (art, creativity and experiences) communicated poorly with a commentator using justifications typical of the world of the market. 
The city of Helsinki could have proactively encouraged communication between these actors, thereby encouraging compromise. However, this would have been challenging in any case, because the distance between different worlds was based on incompatible paradigms with different normative principles for making sense of reality (Kagan 2011). The distance of the social worlds is clear in Helsingin Sanomat:

I don't see why the government, the city or any other public authority should invest in a project by a private market-based cultural institution with this volume. If Guggenheim really wants to establish a museum in Helsinki, the Foundation should shoulder the cost.

Boston consulting group seems to know what is best for us.

In Helsinki, the elderly is abandoned. In home care, there are old people with severe dementia who are not able to take care of themselves and therefore feel insecure. Currently a museum which would cost around 130 to 150 million euros is planned with whatever it takes.

A museum combining visual arts, design and architecture with a stable brand is an idea worth carrying out. As an artist I often wonder how the community of artists is so centred on being opposed to everything instead of producing new visions.

The first two opinions above represent academic voices, the third is a citizen's view and the last comment is that of an internationally acclaimed artist.

One group of actors shows interest in the prospects for commercial life and tourism, while another group resists any foreign influence on national culture, and the rest, a large part of the citizens and politicians, insist on putting health care before any artistic investment. Art enthusiasts became indignant over justifications alien to the discourse of art. Because the City did not encourage a comprehensive discussion about the relationship between the Guggenheim museum and the art world, it proved impossible to convince the art world of the benefits a Guggenheim might bring to other art institutions or artists. The chief negotiator referred to the significance of visual and digital culture, but gave no example of how digital culture would be part of the new museum. Further, since Guggenheim Museum Bilbao has diversified Bilbao's art scene, plans aiming at similar or other museum policies could have been outlined. Since this was not done, the impression of the plans for Guggenheim Museum Helsinki was mostly as a tourist destination.

The political climate clearly had an impact on the reception of the Guggenheim museum proposed in Helsinki. The Helsinki Guggenheim story has unfolded in a Nordic capital, and yet, it is intertwined with current European politics affected by nationalistic ideology. This led to calls to preserve local cultures, regarded as authentic, against a globally shared culture. As Juha Herkman (2017) has shown in his analysis of articulations of populism, nationalistic identities were used in the construction of populism in Northern European multi-party democracies. The long period of recession in Europe since 2008 in Europe created prejudices towards other cultures (Martín Artiles and Meardi 2014; Yoxon et al. 2019). Inward-oriented nationalism sees only threats in globalization, as well as the risk of job losses due to immigration. As globalization brings change, politicians are easy targets of criticism, even if their power to influence the changes can be limited (Kettunen 2012: 92-5). There is a certain tension within the Finnish identity that is typical of peripheries, where one's own identity is to be defended against the centre (Hall and Du Gay 1996). Indeed, the criticism of a Guggenheim museum plan in Taichung, Taiwan, at the beginning of the twenty-first century, has similarities with the debate on the Helsinki museum proposal: the Taichung plan was rejected under pressure from citizens and the art world fearful of the effect that imported American cultural concepts would have on the city. ${ }^{8}$ 


\section{Conclusion}

In all, when looking at the debate, it seems likely that those criticizing the Guggenheim proposal were right in emphasizing the economic risks and in pointing out that a museum based on an American franchise museum would not contribute to the Finnish art scene as expected. The outcome of improving the brand of the City of Helsinki by means of a Guggenheim brand is most uncertain and the 20 million euro cost for the use of the Guggenheim brand may simply be too high. Perhaps the Guggenheim Foundation needs Helsinki more than Helsinki needs it, as cultural economist Aku Alanen (2012: 83-4) has stated.

Willingness to participate in culture is quite strong in the Helsinki capital region but, particularly among younger generations, there is an even greater interest in urban events and festivals than towards museum visits, for example (Linko and Silvanto 2011). Helsinki's reputation probably lies in innovations in digital technology and games, and vitality has grown primarily in the form of civic grassroots activism in line with Richard Florida's (2002) famous theses about favouring a liberal atmosphere, education and creativity, which create well-being, joy and vibrancy, but also visitors and investments. They involve bottom-up processes, as well as open-minded experimentation enabled by social media. ${ }^{9}$ In this respect, museum studies, especially research into the changing aims of and expanding activities of museums in contemporary culture, benefits from research into city dwellers' and other stakeholders' attitudes and values, and other options for leisure activities.

The intended museum location would have been in a landscape of power, with the main purpose to revitalize the local area by attracting more tourists. Compared to many other cultural regeneration projects at waterfronts discussed earlier, the planned location of the Helsinki Guggenheim museum would not be in an area in need of urban regeneration. Because the economic structure throughout this Nordic capital is diverse and the level of education high, the new museum would not be part of a larger plan of structural changes, as was the case of Glasgow and Bilbao. The presidential palace and City Hall nearby represent power and stability. The area does not lack wealth but rather urban liveliness. During the summer months, cruise ships anchor close to the site and the open-air marketplace is also close by, but otherwise there is not an abundance of places to visit. Therefore, the museum might have become a monument with few connections to other uses of city space, unless it created new ones. In general, the effects of a new museum should affect citizens over a large area, as Daniel Paül i Agustí (2014: 492) points out in his study on the differences in the location of urban museums. From this point of view, the Guggenheim Museum Helsinki plan was not an exception, as the locations of several new flagship museums have not been the result of exhaustive planning or a process of reaching consensus with the local community, and typically there has been no real debate on the advantages of different types of museum sites (Evans and Foord 2008; Paül i Agustí 2014). In comparison, the open space in front of the Museum of Contemporary Art, Kiasma, is a favourite spot for skateboarders; nearby, the terraced grass plateau at the new Music House is a popular place to spend time in summer and the city library next to it has attracted some 2 million visitors since its opening in 2018. On the other hand, the opportunity to erect an interesting building on the seashore in the city centre seemed like a good solution for an empty site. However, choosing this location close to the presidential palace probably cemented opponents' views on the aims of this project, that of fostering economic life and tourism at the expense of answering citizens' cultural wishes.

Culture-led development projects or major branding ideas such as public investments in museums have proved a challenged urban policy arena because the demands of society, including public and private interests, have clashed more than once. The entire debate can be looked at in a positive light: as opposed to a largely criticized Guggenheim Museum Abu Dhabi project, in the case of the Helsinki museum plan, democratic governance generated a high degree of collective intelligence, involved multiple stakeholders and allowed critical evaluations that were beneficial in decreasing the proneness to risk (Ponzini et al. 2019). Different stakeholders' objectives, together with the regulatory power of the public sector, make it difficult to agree on content and processes and to reach a consensus. These processes can only be successful if a large amount of institutional and individual creativity were invested in resolving the relevant issues, as many contradictory interests need to be reconciled. This requires 
communication and moderation (IImonen and Kunzmann 2007: 283). When the Guggenheim plan was introduced for the first time, the City of Helsinki appears to have maintained an illusion of being able to offer a ready-made package to citizens and other stakeholders after closed-door negotiations. As I aimed to show by the analysis of justifications used during a debate on the prospect of a new flagship museum, in a mediatized and democratic society that enables citizen participation, attitudes of the citizens may change quickly and this may have immediate effects on the views of decision-makers and for the fate of the project. The result is an empty lot.

Received: 10 June 2019

Finally accepted: 27 August 2020

\section{Acknowledgements}

Special thanks to excellent research assistants Joonas Tuhkuri, MIT and Virve Pirttikoski, University of Helsinki.

\section{Notes}

1 The Solomon R. Guggenheim Foundation, 'Concept and Development Study for a Guggenheim Helsinki', 2011. https://www.hel.fi/hel2/kanslia/guggenheim/ps/concept and development_study for_a_guggenheim_helsinki_a3.pdf, accessed 5 August 2020.

2 See Guggenheim Helsinki, http://www.guggenheimhki.fi/en/.

3 The Solomon R. Guggenheim Foundation', Concept and Development Study'.

4 City of Helsinki, 'Guggenheim Study', 1 December 2016. https://www.hel.fi/helsinki/en/ culture/culture/exhibitions/guggenheim-study-2014, accessed 5 August 2020.

5 City of Helsinki, 'City Board', 2019. https://www.hel.fi/helsinki/en/administration/decision/ board, accessed 24 May 2020

6 Helsingin Sanomat ordered a survey from TNS Gallup and the results of the survey were published in Helsingin Sanomat on 8 March 2012. Pipsa Palttala, 'Residents of the Capital Region reject the Guggenheim', Helsingin Sanomat 2012. https://www.hs.fi/kotimaa/art2000002522720.html, accessed 13 October 2020.

7 Kristen Purcell, Lee Rainie, Amy Mitchell, Tom Rosenstiel and Kenny Olmstead, 'Understanding the Participatory News Consumer: How Internet and Cell Phone Users Have Turned News into a Social Experience', Pew Internet and American Life Project 2010. Available at: https://www.journalism.org/2010/03/01/understanding-participatorynews-consumerl, accessed 16 October 2020.

8 Debby Wu, 'Cultural Invasion by Guggenheim Museum Feared', Taipei Times 23 November 2003. https://www.taipeitimes.com/News/taiwan/archives/2003/11/23/2003076934, accessed 16 October 2020.

9 Sampo Ruoppila and Panu Lehtovuori, 'Guggenheim Helsinki: Landing-site for Franchised Culture', Domus 2012. https://www.domusweb.it/en/opinion/2012/03/07/guggenheimhelsinki-landing-site-for-franchised-culture.html, accessed 16 October 2020.

\section{References}

Aalst, I. and Boogarts, I. (2002) 'From Museum to Mass Entertainment. The Evolution of the Role of Museums in Cities', European Urban and Regional Studies, 9 (3) 195209. 
Alanen, A. (2012) 'Culture and Regional Economy' [in Finnish], in Kaarin Taipale (ed) Guggenheim's Shadow, 81-96, Helsinki: Into.

Baniotopoulou, E. (2001) 'Art for Whose Sake? Modern Art Museums and their Role in Transforming Societies: The Case of Guggenheim Bilbao', Journal for Conservation and Museum Studies, 7 1-5.

Bauman, Z. (2001) [1997] Thinking Sociologically, London: Wiley.

Bayliss, D. (2007) 'The Rise of the Creative City: Culture and Creativity in Copenhagen', European Planning Studies, 15 (7) 889-903.

Bianchini, F., Dawson, J. and Evans, R. (1993) 'Flagship Projects in Urban Regeneration', in Patsy Healey, Simin Davoudi, Mo O'Toole, Solmaz Tavsanoglu and David Usher (eds) Rebuilding the City: Property-led Urban Regeneration, 245-55, London: E and FN Spon.

Boltanski, L. and Thévenot, L. (1999) 'The Sociology of Critical Capacity', European Journal of Social Theory, 2 (3) 359-77.

(2006) [1991] On Justification. Economies of Worth, New Jersey: Princeton Press.

Desfor, G. and Jørgensen, J. (2004) 'Flexible Urban Governance. The Case of Copenhagen's Recent Waterfront Development', European Planning Studies, 12 (4) 479-96.

Evans, G. (2003) 'Hard Branding the Cultural City. From Prado to Prada', International Journal of Urban and Regional Research, 27 (2) 417-40.

(2005) 'Measure for Measure: Evaluating the Evidence of Culture's Contribution to Regeneration', Urban Studies, 42 (5-6) 959-83.

Evans, G. and Foord, J. (2008) 'Cultural Mapping and Sustainable Communities: Planning for the Arts Revisited', Cultural Trends, 17 (2) 65-96.

Florida, R. (2002) The Rise of the Creative Class: And How It's Transforming Work, Leisure, Community and Everyday Life, New York: Basic Books.

García, B. (2004) 'Urban Regeneration, Arts Programming and Major Events', International Journal of Cultural Policy, 10 (1) 103-18.

Gibson, L. (2008) 'In Defence of Instrumentality', Cultural Trends, 17 (4) 247-57.

Gray, C. (2007) 'Commodification and Instrumentality in Cultural Policy', International Journal of Cultural Policy, 13 (2) 203-16.

Grodach, C. (2008) 'Museums as Urban Catalysts: The Role of Urban Design in Flagship Cultural Development', Journal of Urban Design, 13 (2) 195-212.

(2010) 'Beyond Bilbao: Rethinking Flagship Cultural Development and Planning in Three California Cities', Journal of Planning Education and Research, 29 (3) 35366.

(2013) 'Cultural Economy Planning in Creative Cities: Discourse and Practice', International Journal of Urban and Regional Research, 37 (5) 1747-65.

Hadley, S. and Gray, C. (2017) 'Hyperinstrumentalism and Cultural Policy: Means to an End or an End to Meaning?', Cultural Trends, 26 (2) 96-102. 
Hall, S. and Du Gay, P. (eds) (1996) Questions of Cultural Identity, London: Sage.

Herkman, J. (2017) 'Articulations of Populism: The Nordic Case', Cultural Studies, 31 (4) 470-88.

Hjarvard, S. (2008) 'The Mediatization of Society. A Theory of the Media as Agents of Social and Cultural Change', Nordicom Review, 29 (2) 105-34.

(2013) The Mediatization of Culture and Society, London: Routledge.

Hjarvard, S., Mortensen, M. and Eskjær, M.F. (2015) 'Three Dynamics of Mediatized Conflicts', in Mikkel Fugl Eskjær, Stig Hjarvard and Mette Mortensen (eds) The Dynamics of Mediatized Conflicts, New York: Peter Lang.

IImonen, M. and Kunzmann K.R. (2007) 'Culture, Creativity and Urban Regeneration', in Arabianranta Rethinking Urban Living, 278-84, Helsinki: City of Helsinki Urban Facts and Art and Design City of Helsinki.

Kagan, S. (2011) Art and Sustainability. Connecting Patterns for a Culture of Complexity, New Brunswick and London: Transaction.

Kagan, S. and Kirchberg, V. (eds) (2008) Sustainability. A New Frontier for the Arts and Cultures, Frankfurt: Vas-Verlag.

Kettunen, P. (2012) 'Kansallinen Toimijuus Suomalaisessa politiikassa' [in Finnish], in Kari Paakkunainen (ed) Suomalaisen politiikan murroksia ja muutoksia, 75-98, Helsinki: University of Helsinki, Department of Politics and Economics.

Lee, H. (2015) 'Branding the Design City', International Journal of Cultural Policy, 21 (1) $1-19$.

Linko, M. and Silvanto, S. (2011) 'Infected by Arts Festivals: Festival Policy and Audience Experiences in the Helsinki Metropolitan Area', International Journal of Arts Management, Law, and Society, 41 (4) 224-39.

Luhtakallio, E. (2012) Practicing Democracy. Local Activism and Politics in France and Finland, Houndmills: Palgrave.

Luhtakallio, E. and Ylä-Anttila, T. (2011) 'Julkisen Oikeuttamisen Analyysi Sosiologisena Tutkimusmenetelmänä' [in Finnish with English abstract], Sosiologia, 48 (1) 34-51.

Markusen, A. and Gadwa, A. (2010) 'Arts and Culture in Urban or Regional Planning: A Review and Research Agenda', Journal of Planning Education and Research, 29 (3) 379-91.

Martín Artiles, A. and Meardi, G. (2014) 'Public Opinion, Immigration and Welfare in the Context of Uncertainty', Transfer: European Review of Labor and Research, 20 (1) 53-68.

Mickelsson, R. (2012) 'Finnish Political Parties as Narratives' [in Finnish], in Kari Paakkunainen (ed) Suomalaisen Politiikan Murroksia ja Muutoksia, Helsinki: University of Helsinki, Department of Politics and Economics.

Miles, S. (2005) "“Our Tyne": Iconic Regeneration and the Revitalisation of Identity in NewcastleGateshead', Urban Studies, 42 (5-6) 913-26.

Mäenpää, P. (2011) Helsinki Back on its Feet [in Finnish], Helsinki: Gaudeamus. 
Paül i Agustí, D (2014) 'Differences in the Location of Urban Museums and their Impact on Urban Areas', International Journal of Cultural Policy, 20 (4) 471-95.

Plaza, B. (2000) 'Evaluating the Influence of a Large Cultural Artifact in the Attraction of Tourism. The Guggenheim Museum Bilbao Case', Urban Affairs Review, 36 (2) 26474.

(2006) 'The Return on Investment of the Guggenheim Museum Bilbao', International Journal of Urban and Regional Research, 30 (2) 452-67.

(2008) 'On Some Challenges and Conditions for the Guggenheim Museum Bilbao to be an Effective Economic Re-activator', International Journal of Urban and Regional Research, 32 (2) 506-17.

Plaza, B. and Haarich, S. (2008) 'The Guggenheim Museum Bilbao in Scientific Journals: Asymmetries Between the American Art Perspective and the European Regional Planning Viewpoint', MPRA Paper No 10751. Available at https://mpra.ub.unimuenchen.de/10751/.

(2009) 'Museums for Urban regeneration? Exploring Conditions for their Effectiveness', Journal of Urban Regeneration and Renewal, 2 (3) 259-71.

(2015) 'The Guggenheim Museum Bilbao: Between Regional Embeddedness and Global Networking', European Planning Studies, 23 (8) 1456-75.

Plaza, B., Tironi, M. and Haarich, S. (2009) 'Bilbao's Art Scene and the "Guggenheim Effect” Revisited', European Planning Studies, 17 (11) 1711-29.

Ponzini, D. (2010) 'Bilbao Effects and Narrative Defects'. Cahiers de recherche du Programme Villes \& territoires 2010. Paris: Sciences Po.

Ponzini, D. and Nastasi, M. (2011) Starchitecture - Scenes, Actors and Spectacles in Contemporary Cities, Turin: Umberto Allemandi.

Ponzini, D. and Ruoppila, S. (2018) 'Local Politics and Planning Over Transnational Initiatives: The Case of Guggenheim Helsinki', Journal of Urban Design, 23 (2) 22338.

Ponzini, D., Ruoppila, S. and Jones, Z.M. (2019) 'What Difference Does Democratic Local Governance Make? Guggenheim Museum Initiatives in Abu Dhabi and Helsinki', Geography, Urban Studies and Planning, 38 (2) 347-65.

Richards, G. (ed) (2001) Cultural Attractions and European Tourism, Tilburg: Tilburg University Department of Leisure Studies.

Rosenbaum, S. (2011) Curation Nation: How to Win in a World Where Consumers are Creators, New York: McGraw-Hill.

Serota, N. and Hyslop, D. (2011) 'Art and Culture in Regeneration. Tate Modern, Bankside and London', Journal of Urban Regeneration and Renewal, 4 (4) 328-36.

Smith, A. and von Krogh Strand, I. (2011) 'Oslo's new Opera House: Cultural Flagship, Regeneration Tool or Destination Icon?', European Urban and Regional Studies, 18 (1) 93-110.

Strömbäck, J. and Esser, F. (2015) 'Introduction: Making Sense of Mediatized Politics', in Jesper Strömbäck and Frank Esser (eds) Making Sense of Mediatized Politics. Theoretical and Empirical Perspectives, 1-14, London: Routledge. 
Villi, M. (2012) 'Social Curation in Audience Communities: UDC (User-Distributed Content) in the Networked Media Ecosystem', Participations: The International Journal of Audience \& Reception Studies, 9 (2) 618-32.

Ylä-Anttila, T. and Kukkonen, A. (2014) 'How Arguments are Justified in the Media Debate on Climate Change in the USA and France', International Journal of Innovation and Sustainable Development, 8 (4) 394-408.

Yoxon, B., Van Hauwaert, S.M. and Kiess, J. (2019) 'Picking on Immigrants: A CrossNational Analysis of Individual-level Relative Deprivation and Authoritarianism as Predictors of Anti-foreign Prejudice', Acta Politica, 54 (3) 479-520.

\title{
Author
}

Maaria Linko

ORCID iD: https://orcid.org/0000-0002-4618-842X

https://tuhat.helsinki.fi/portal/en/persons/maaria-linko(63f3424a-08ab-45b4-803e$\underline{\mathrm{f} 15 \mathrm{e} 93 \mathrm{~d} 425 \mathrm{c} 2) \cdot \mathrm{html}}$

\author{
Adjunct Professor \\ University of Helsinki, \\ Finland
}

Email: maaria.linko@helsinki.fi 